\title{
Oil Prices and the U.S. Dollar Exchange Rate: Evidence from the Monetary Model
}

\author{
Moayad H. Al Rasasi ${ }^{1, *}$ \\ ${ }^{1}$ Economic Research Department, Saudi Arabian Monetary Authority, Riyadh, Saudi Arabia \\ *Correspondence: Economic Research Department, Saudi Arabian Monetary Authority, \\ Riyadh, Saudi Arabia. Tel: 966-11-463-3000. E-mail: moalrasasi@ gmail.com
}

Received: September 16, 2018 Accepted: October 16, 2018 Published: December 18, 2018

doi: 10.5296/rae.v10i4.14076 URL: https://doi.org/10.5296/rae.v10i4.14076

\begin{abstract}
This paper analyzes how changes in global oil prices affect the US dollar (USD) exchange rate based on the monetary model of exchange rate. We find evidence indicating a negative relationship between oil prices and the USD exchange rate against 12 currencies. Specifically, the analysis of the impulse response function shows that the depreciation rate of the USD exchange rate ranges between 0.002 and 0.018 percentage points as a result of a one-standard deviation positive shock to the real price of crude oil. In the same vein, the forecast error variance decomposition analysis reveals that variation in the USD exchange rate is largely attributable to changes in the price of oil rather than monetary fundamentals. In last, the out-of-sample forecast exercise indicates that oil prices enhance the predictability power of the monetary model of exchange rate.
\end{abstract}

Keywords: Oil Prices; US Dollar; Monetary Model of Exchange Rate; Forecasting 


\section{Introduction}

Even though the monetary models of exchange rates became the standard instrument of analysis in international finance after the collapse of the Bretton Woods system in 1973, the performance of monetary models in explaining the behavior of nominal exchange rate is still unsatisfactory. Extensive reviews of traditional exchange rate models (Meese, 1990; Meese and Rose, 1991; MacDonald and Taylor, 1992; Frankel and Rose, 1995; Neely and Sarno, 2002; Chueng, et al., 2005) not only summarize the difficulties of these models, but also point out to the lack of these traditional models in capturing the exchange rate volatility.

This in turn encourages other economists, such as, Groen (2000), Cheung et al. (2005), and Chinn and Moore (2011), to advocate the notion of the flexibility of any model of exchange rate determination. Based on this notion, it is possible to incorporate other non-monetary determinants that might justify the movement of exchange rates into the monetary models of exchange rates. Cheung et al. (2005), for example, embed other non-monetary determinants such as government debt, terms of trade and net foreign assets into monetary models of exchange rates to examine whether these non-monetary variables capture the movements of exchange rates or not. Likewise, Chinn and Moore (2011) augmented monetary model of exchange rates with order flow variables to predict exchange rates. Hunter and Ali (2014) estimated the augmented monetary model of exchange rates with the real stock price, the government consumption as a percentage of GDP, and the productivity in the traded sector to investigate exchange rate persistence. In sum, the findings of these studies confirm that non-monetary fundamentals contain useful information explaining exchange rate variations.

Another strand of the literature (i.e. Amano and Norden 1998, Chen and Rogoff 2003, Chen and Chen 2007, Narayan et al. 2008, and Uddin et al. 2014) documents the influential role of commodity prices on the movements of exchange rates, although these studies are based on atheoretical models. Therefore, this motivates us to rely on theoretical models of exchange rate determination, such as the monetary model of exchange rate, instead of atheoretical models upon which existing literature relies (Note 1).

Further motivation to incorporate the monetary model with oil prices is that oil prices impact the US dollar through the money demand channel. Put in a different way, because the USD is the main settlement currency in international crude oil markets, oil prices impact the USD through the US money demand function directly. Since oil-importing countries need to buy the USD to purchase crude oil, their purchases increase the demand for the USD in international currency markets.

By augmenting the flexible monetary model of exchange rates with oil prices, we contribute to the literature in two ways. First, examining the relationship between oil prices and the USD exchange rate in the monetary model framework is unique. Examining whether oil prices enhance the predictability of the monetary model using out-of-sample forecasts is the other contribution.

The reminder of the paper is organized in the following order. The next section reviews existing literature linking oil prices to exchange rates. Section three introduces the flexible price monetary model of exchange rates, augmented with the oil price effect. Section four describes the dataset and section five outlines the empirical methodology. Section six 
discusses the results, while section seven contains the conclusion and discusses the policy implications.

\section{Literature Review}

In the seminal work of Meese and Rogoff (1983), they document the failure of various monetary models and time series models of exchange rate determination in predicting the movements of exchange rates. Since then, there has been extensive research attempting to explain the movements of exchange rates. This, in turn, encourages scholars to look for other factors that might be able to explain and to predict exchange rate movements. For example, Lastrapes (1992) identifies three real shocks, productivity growth, the government budget deficit, and real oil prices, to explore their effects on real exchange rates. The obtained evidence shows that these real shocks succeeded in explaining more than $80 \%$ of exchange rate variations in the long run.

Clarida and Gali (1994) employ the Blanchard-Quah identification scheme to explore the consequences of real shocks, including demand, supply, and money, on the bilateral real exchange rate of the US dollar against the currencies of Canada, Germany, Japan, and the UK. They conclude that real shocks contribute to the variation in real exchange rate by more than $50 \%$ of the variance of the real exchange rate variability. Other authors (Throop, 1993; Evans \& Lothian, 1993; \& Zhou, 1995) confirm that non-monetary shocks play an influential and significant role in capturing the variations of exchange rates.

Moreover, other studies, based on atheoretical models, document the explanatory power of oil prices in capturing the movements of exchange rates, starting with Amano and Norden (1998), who examine the essential role of oil prices on real exchange rates of three major currencies with monthly data over the period 1973:01 to 1993:06. The outcome of their analysis supports the existence of a stable long run relationship between oil prices and real exchange rates. Specifically, their finding indicates that higher oil prices lead to the appreciation of the US dollar and the depreciation of the German mark and the Japanese yen.

Chaudhuri and Daniel (1998) use the data of 16 OECD countries to examine the effects of oil prices on the US real exchange rate. They report that oil prices can explain the fluctuations of the US real exchange rate, since both oil prices and real exchange rates have the same nonstationary behavior. They also find evidence in favor of the idea that higher oil prices lead to the appreciation of the US dollar against all countries. Likewise, Sadorsky (2000) uses various energy prices, containing crude oil prices, to examine their impacts on the trade-weighted US exchange rate. Sadorsky reports evidence supporting the existence of a long run relationship between energy prices and the US dollar exchange rate. He also finds a negative relationship between energy prices and the USD exchange rate.

Akram (2004) studies the possibility of a non-linear cointegration relationship between oil prices and the Norwegian exchange rate. He finds evidence favoring the notion of a negative relationship between oil prices and exchange rates. In addition, Chen and Chen (2007) adopt panel cointegration techniques to evaluate the relationship between real oil prices and 
the US dollar exchange rate against G7 countries. Their empirical results not only confirm the presence of a cointegration relationship between oil prices and exchange rates, but also confirm that oil prices are able to predict the movements of exchange rates.

Based on volatility models, Narayan, et al. (2008) employ both the GARCH and exponential GARCH models to assess the nominal exchange rate of the Fiji Islands and its movement against the US dollar in response to oil price fluctuations. Their analyses suggest the negative relationship between oil prices and the US dollar relative to the Fiji exchange rate. Jahan-Parvar and Mohammadi (2008) investigate the relationship between oil prices and the real exchange rate for 14 oil-producing countries based on an autoregressive distributed lag model. They conclude the existence of a stable long run relationship between oil prices and exchange rates confirming the validity of the Dutch disease hypothesis. In an alternative paper, Mohammadi and Jahan-Parvar (2012) employ threshold and momentum-threshold models to explore the validity of the Dutch disease hypothesis for 13 oil-exporting countries. They find evidence supporting the validity of the Dutch disease for only three countries; i.e., the US dollar tended to depreciate relative to the Bolivian boliviano, Mexican peso, and Norwegian krone. To this end, there are other studies (Huang and Guo, 2007; Thalassinos and Politis, 2012; Uddin et al., 2014; Al Rasasi \& Yilmaz, 2016; Al Rasasi, 2015, 2017, 2018) documenting the essential role of oil prices in capturing the behavior of exchange rates.

\section{The Monetary Model of Exchange Rate Determination}

The monetary model of exchange rate determination posits the link between the nominal exchange rate and a simple set of monetary fundamentals counting for output, money supply, and interest rates. The plain intuition of the monetary model of exchange rates is that a country's price level is determined by its demand and supply for money and that the price level in foreign countries should be the same when it is expressed in the same currency. This makes the monetary model an attractive theoretical tool in understanding exchange rate fluctuations over time.

The monetary model of exchange rate under flexible prices consists of money market equilibrium, purchasing power parity (PPP), and uncovered interest parity (UIP). In the money market, the money demand function usually depends on the price level, $p$, real income,

$y$, and the level of the interest rate, $i$. However, some studies augment the money demand function with other determinants, such as real effective exchange rates and the inflation rate (Bahmani-Oskooee and Malixi, 1991), the interest rate spread (Valadkhani, 2008), opportunity cost of holding money, the real value of wealth, and investor confidence (Hall et al., 2012).

Since the US dollar is the primary invoicing currency in international crude oil markets, this in turn suggests that changes in oil prices affect the US money demand function directly.

Therefore, we incorporate the real oil price $\left(O_{t}\right)$ into the US money demand function, so the augmented money demand function of the US is given as follows: 


$$
\frac{m_{t}}{p_{t}}=L\left(y_{t}, i_{t}, O_{t}\right)
$$

where $\frac{m_{t}}{p_{t}}$ denotes the real money demand. On the other hand, we assume that the money demand function of the foreign country depends only on the price level, $p$, real income, $y$, and the level of the interest rate, $i$, and is given as follows:

$$
\frac{m_{t}^{*}}{p_{t}^{*}}=L\left(y_{t}^{*}, i_{t}^{*}\right)
$$

In money market equilibrium, money demand must equal money supply. Hence, the money demand functions given by equations (1) and (2) for both domestic and foreign countries, where asterisks denote the foreign country's variables, can be written:

$$
\begin{gathered}
m_{t}-p_{t}=\phi y_{t}-\lambda i_{t}+\delta O_{t} \\
m_{t}^{*}-p_{t}^{*}=\phi y_{t}^{*}-\lambda i_{t}^{*}
\end{gathered}
$$

where $0<\phi<1$ is the income elasticity of money demand; $\lambda>0$ is the interest rate semi-elasticity of money demand; and $\delta>0$ is the oil price elasticity. This relationship is true because crude oil is priced in US dollars and higher oil prices increase demand for the US dollar, resulting in an appreciation of the US dollar. All variables, with the exception of interest rates, are expressed in logarithm form. Under the flexible price monetary model, the standard PPP relationship is assumed to hold continuously:

$$
e_{t}=p_{t}-p_{t}^{*}
$$

where $e_{t}$ represents the nominal exchange rate measured in foreign currency to domestic currency. Since the price levels determine the domestic and foreign money supplies, as in equation (1.5), the price level functions can be presented as follows:

$$
\begin{gathered}
p_{t}=m_{t}-\phi y_{t}+\lambda i_{t}-\delta O_{t} \\
p_{t}^{*}=m_{t}^{*}-\phi y_{t}^{*}+\lambda i_{t}^{*} .
\end{gathered}
$$

Therefore, we substitute equations (6) and (7) into equation (5) to obtain the exchange rate, 
$e_{t}$, as follows:

$$
e_{t}=\left(m_{t}-\phi y_{t}+\lambda i_{t}-\delta O_{t}\right)-\left(m_{t}^{*}-\phi y_{t}^{*}-\lambda i_{t}^{*}\right)
$$

This can be simplified to:

$$
e_{t}=\left(m_{t}-m_{t}^{*}\right)-\phi\left(y_{t}-y_{t}^{*}\right)-\delta O_{t}+\lambda\left(i_{t}-i_{t}^{*}\right)
$$

Note that the monetary model of the exchange rate under flexible prices assumes that UIP, which equates the interest rate differential between two countries to the future change in exchange rate, holds. The UIP condition is given by the following equation:

$$
i_{t}-i_{t}^{*}=E\left(\Delta e_{t+1} \mid \Omega_{t}\right)
$$

where $E\left(. \mid \Omega_{t}\right)$ represents the expectation of future change in nominal exchange rate based on the information set $\Omega$ at the current time period. Then, equation (9) becomes

$$
e_{t}=\left(m_{t}-m_{t}^{*}\right)-\phi\left(y_{t}-y_{t}^{*}\right)-\delta O_{t}+E\left(\Delta e_{t+1} \mid \Omega_{t}\right)
$$

If $e_{t}$ is $I(0)$ or $I(1)$, then $\Delta e_{t+1}$ will equal to zero in the steady state, as in Rapach and Wohar (2002). Thus, equation (11) will become:

$$
e_{t}=\left(m_{t}-m_{t}^{*}\right)-\phi\left(y_{t}-y_{t}^{*}\right)-\delta o_{t}
$$

Based on equation (12), we can infer that a rise in the domestic money supply relative to the foreign money supply, ceteris paribus, leads to the appreciation of the nominal exchange rate $\left(e_{t}\right)$. On the other hand, a rise in domestic output relative to foreign output, ceteris paribus, causes the depreciation of the nominal exchange rate $\left(e_{t}\right)$. Regarding the impact of oil price increases, a rise in oil prices leads to the depreciation of the nominal exchange rate $\left(e_{t}\right)$.

\section{Data}

We use quarterly data over the period 1986:Q1 to 2014:Q3 for the nominal exchange rate of the US dollar, West Texas intermediate crude oil prices, GDP, and money supply for the following 14 countries: Australia, Canada, Chile, Denmark, Japan, Mexico, New Zealand, Norway, South Africa, South Korea, Sweden, Switzerland, the United Kingdom (U.K.), and the United States of America (US). The composition of the sample is determined by data availability. In addition, these countries are major trade partners of the US, and the currencies of these countries are actively traded in the international currency market.

The data for GDP and oil prices are obtained from the International Financial Statistics (IFS) database of the International Monetary Fund (IMF) and Federal Reserve Bank of St. Louis, 
respectively. The nominal exchange rate is measured as US dollar per one unit of foreign currency; thus, an increase in the nominal exchange rate means a depreciation of the USD. Money supply is measured by the broad money supply, M3. The nominal exchange rate and money supply data are obtained from the Organization for Economic Co-operation and Development (OECD) database. It is also essential to emphasize that all the data are expressed in logarithm form.

\section{Empirical Methodology}

\subsection{Preliminary Investigation}

The first step of the analysis is to ascertain the order of integration of the economic variables. To do so, we rely on some standard unit root tests that include the Augmented Dickey-Fuller (1979), the Phillip Perron (1988), and the Kwiatkowski, Phillips, Schmidt and Shin (1992) tests to ensure the stationarity of the economic variables. Next, in case the economic variables are integrated of order one or I (1), then there might be a possibility to find that some of these variables are cointegrated as pointed out by Engle and Granger (1987). To check this, we apply the popular cointegration tests developed by Johansen and Juselius (1990). The cointegration tests would also enable us to gauge the suitability of modeling the US nominal exchange rate as a function of oil prices and monetary fundamentals.

Likewise, it is essential to assess the stability of the relationship between the USD exchange rate, oil prices, and monetary fundamentals. To achieve this, we employ the Quandt-Andrews unknown breakpoint tests developed by Andrews (1993) and Andrews and Ploberger (1994). The essential idea behind the Quandt-Andrews unknown breakpoint does not assign any information regarding the breakpoints prior to the estimation and identifies the breakpoints by comparing the residuals before and after the presumed point of break for every time period. The test statistics are summarized as SupF, Ave F and Exp F, with all sharing the same null hypothesis of no structural change.

\subsection{The Vector Error Correction Model}

It is common in the literature to use Vector Autoregressive (VAR) models as empirical tools to investigate the effects of oil price shocks on various macroeconomic and financial variables. However, the standard VAR model is a reduced form model. Interpreting the results obtained from the reduced form is often impossible, unless the reduced form VAR is linked to an economic model. Put in a different way, when economic theory provides an explanation linking forecast errors and fundamental shocks, then we call the resulting model a Structural Vector Autoregressive (SVAR) model. In case there exists a cointegration relationship among the economic variables, then it is possible to apply the SVAR technique to vector error correction models (VECM) with cointegrated variables.

The analysis of a structural vector error correction (SVEC) model starts from the reduced form standard VAR $(p)$ model:

$$
X_{t}=A_{1} X_{t-1}+A_{2} X_{t-2}+\cdots+A_{p} X_{t-p}+u_{t}
$$


where $X_{t}=\left(O_{t}, Y_{t}, e_{t}, M_{t}\right)^{v}$ is a $k \times 1$ vector of observable variables consisting of real oil price, domestic output relative foreign output, nominal exchange rate of the USD, and domestic money supply relative to foreign money supply. The $A_{i}^{\prime} s$ are $(k \times k)$ coefficient matrices, and $u_{t}$ is a $(k \times 1)$ vector of unobservable error terms with $u_{t} \sim\left(0, \Sigma_{u}\right)$. The lag order, $p$, is determined based on the Akaike Information Criterion (AIC).

By assuming that the variables are at most difference stationary, then the reduced form VAR model can be written as a VECM of the form:

$$
B_{0} \Delta X_{t}=\Pi^{*} X_{t-1}+\Gamma_{1}^{*} \Delta X_{t-1}+\cdots+\Gamma_{p-1}^{*} \Delta X_{t-p+1}+\varepsilon_{t}
$$

where $\Delta$ denotes the first difference of $X_{t-k}, \Gamma^{* t} s$ are $(k \times k)$ matrices of short run coefficients. $\Pi^{*}$ is the structural matrix, and $\varepsilon_{t}$ is $(k \times 1)$ structural form error with zero mean and covariance matrix $I_{K} . B_{0}$ is a $(k \times k)$ matrix of contemporaneous relations among the variables in $X_{t}$. If we assume that the $B_{0}$ matrix is invertible, then we can rewrite equation (14) as follows:

$$
\Delta X_{t}=\Pi X_{t-1}+\Gamma_{1} \Delta X_{t-1}+\cdots+\Gamma_{p-1} \Delta X_{t-p+1}+u_{t}
$$

where $\Pi_{t}=B_{0}^{-1} \Pi^{*}$ and $\Gamma_{j}=B_{0}^{-1} \Gamma_{j}^{*}$ for $j=1, \ldots, p-1$. The $u_{t}=B_{0}^{-1} \varepsilon_{t}$ relates the reduced form disturbance, $u_{t}^{t}$, to the underlying structural errors $\varepsilon_{t}$. When $\Pi$ has a reduced rank of $r \leq k-1$, then $\Pi=\alpha \beta^{\prime}$ where $\alpha$ and $\beta$ are $(k \times r)$ matrices consisting of the long run relationship and the speed of adjustment coefficients, respectively. The vector, $u_{t}$, is a $(k \times 1)$ white noise error with zero mean and covariance matrix $\Sigma_{u}$. When we substitute $\Pi$ into equation (15), we obtain the model in error correction form as follows:

$$
\Delta X_{t}=\alpha \beta^{\prime} X_{t-1}+\Gamma_{1} \Delta X_{t-1}+\cdots+\Gamma_{p-1} \Delta X_{t-p+1}+u_{t}
$$

Because the reduced form residuals, $u_{t}^{\prime} s$, are strongly correlated, it is difficult to eliminate the effects of a single shock on the whole system unless some restrictions are imposed on the system. To do so, we multiply both sides by $B_{0}$ in order to obtain,

$$
\begin{gathered}
B_{0} u_{t}=\varepsilon_{t} \\
\Sigma=B_{0}^{-1} \Sigma_{s}\left(B_{0}\right)^{r},
\end{gathered}
$$

where $\Sigma, B_{0}$, and $\Sigma_{s}$ are all $(\mathrm{k} \times \mathrm{k})$ matrices. Since the literature has proposed a number of different exact identification schemes, we rely on the most popular Cholesky identification scheme to obtain an exact identification of $\Sigma_{s}$ requiring the imposition of $k \times(k-1) / 2$ additional restrictions on $B_{0}^{-1}$. Under the Cholesky scheme, the ordering of the variables is crucial for the structural economic interpretation of the VECM. Therefore, we order the variables as follows: real oil price, relative output, nominal exchange rate of the USD, and relative money supply; $X_{t}=\left(O_{t}, Y_{t}, e_{t}, M_{t}\right)^{r}$. 


\section{Mll Macrothink}

The economic justification of this recursive ordering is based on four reasons. Firstly, since the US is a price taker in the oil market, and the price of crude oil is determined by global demand and supply conditions, then the relative output, exchange rate, and relative money supply will have negligible effects on it. Hence, the price of crude oil is assumed to be exogenous. However, the price of oil can have a contemporaneous effect on the other variables. In other words, a rise (decline) of oil price would increase (decrease) the cost of production, since crude oil is used as an input in the production process and the distribution process of goods and services. Secondly, relative output is assumed to not respond contemporaneously to any changes in relative money supply and exchange rate. Kim and Ying (2007) documents that the information about money supply and exchange rate is only available with a lag, since they are not observable within a month. Thirdly, we impose the restriction that nominal exchange rates do not respond to changes in relative money supply. Fourthly, since the relative money supply is a policy variable and controlled by monetary authorities, we allow the relative money supply to respond to changes in the other variables.

Once we estimate the VECM, we compute impulse response functions to examine the effects of each structural shock on the other variables. Therefore, to examine the dynamic effects of each structural shock on the movements of the USD nominal exchange rates, we compute the impulse responses with a one standard deviation band. The analysis of impulse responses is essentially used to trace the dynamic responses of the equations in the VECM to a set of identified structural shocks. In essence, impulse response analysis enables us to trace the dynamic impact of changes in each of the variables in the VECM over time. In addition, the identification assumptions impose that the shock is a one-standard deviation movement of one of the shocks.

\subsection{Out of Sample Forecast}

An alternative way to gauge whether oil prices enhance the predictability of the monetary model of exchange rate determination is through the evaluation of out-of-sample forecasts. Using one-step-ahead out-of-sample forecasts, we compare the forecasting performance of the composite flexible price monetary model containing oil prices, using the composite model, as given by equation (12), relative to the benchmark model derived in Rapach and Wohar (2002), as given below by equation (19).

$$
e_{t}=\left(m_{t}-m_{t}^{*}\right)-\phi\left(y_{t}-y_{t}^{*}\right)
$$

The one-step-ahead out-of-sample forecasts are obtained from a recursive forecasting scheme, which divides the dataset into two subsamples. The first subsample contains the in-sample observations, R. The first subsample is used to estimate the model coefficients; the second subsample is then used to generate the out-of-sample forecasts, P. In this study, we generate the out-of-sample forecasts recursively from 2010:Q1 to 2014:Q3 in order to forecast the USD exchange rate after the recent financial crisis of 2008; this also implies that $R=96$ and $\mathrm{P}=19$.

To assess the out-of-sample forecast performance, we employ the MSE-T and ENC-T tests of 


\section{Macrothink}

Clark and McCracken (2001) and the mean squared error (MSE) ratio. Clark and McCracken (2001) point out that the Diebold-Mariano (1995) test is not appropriate to compare forecasts of nested models. Hence, they developed tests to assess the forecasting performance of nested models.

Using Clark and McCracken's (2001) method, let $u_{1, t+1}$ and $u_{1, t+2}$ denote the one-step-ahead forecast error from the restricted model, the benchmark model, and the one-step-ahead forecast error from the unrestricted model, the composite model, respectively. Define the loss differential function for the MSE-T as follows:

$$
d_{n, t+1}=u_{1, t+1}^{2}-u_{2, t+1}^{2}
$$

Building on Diebold and Mariano (1995), and Clark and McCracken (2001), develop the MSE-T test of equal forecast accuracy, which is as follows:

$$
M S E-T=(P-1)^{\frac{1}{2}} \frac{\bar{d}_{n}}{\sqrt{S_{d d}}}
$$

where $\bar{d}_{n}$, is the mean of $d_{n}, S_{d d}$ is the variance of $d_{n}$, and $\mathrm{P}$ is the number of one-step-ahead forecasts. Here, the null hypothesis is that $d_{n}=0$, and the alternative hypothesis is that the composite model has a lower MSE - T.

In addition, Clark and McCracken (2001) have developed the ENC-T encompassing test, which draws upon Harvey et al. (1998). Define the loss differential function for the ENC-T as follows:

$$
C_{t+1}=u_{1, t+1}\left(u_{1, t+1}-u_{2, t+1}\right)
$$

The ENC-T encompassing test of Clark and McCracken (2001) is given as follows:

$$
E N C-T=(P-1)^{1 / 2} \frac{\bar{c}}{\sqrt{S_{c c}}}
$$

where $\bar{c}$ is the mean of $C_{t+1}$, and $S_{c c}$ is the variance of $C_{t+1}$. Under the null hypothesis, the benchmark model encompasses the composite model, suggesting that the covariance between $u_{1, t+1}$ and $\left(u_{1, t+1}-u_{2, t+1}\right)$ should be less than or equal to zero. Under the alternative hypothesis, the composite model contains more information suggesting a positive covariance, or the composite model outperforms the benchmark model.

The ENC-T and MSE-T tests are one-sided tests that have been shown to have good size and power properties. The variances of these tests are computed based on the Newey-West HAC consistent covariance estimator. The last measure is the mean squared error (MSE) ratio to gauge the forecasting performance of the benchmark forecast relative to the composite forecast. Based on the mean squared error (MSE) ratio, we test the null hypothesis of equal mean squared error (MSE) of both models. When the MSE ratio equals one, both models 
have the same forecasting power. However, when the MSE ratio is greater than one, the composite model outperforms the benchmark model in forecasting and vice versa.

\section{Empirical Results}

\subsection{Unit Root, Cointegration and Structural Break Tests}

The results of all unit root tests confirm the nonstationarity of all variables in their levels, but do confirm the stationarity of the variables in their first difference. The detailed results are available from the author upon request. Table 1 presents the results of Johansen and Juselius (1990) cointegration tests, which consist of the Trace and the Maximum Eigenvalue tests. Both tests confirm the existence of at least one cointegration relationship among our economic variables.

Table 1. Johansen and Juselius (1990) Cointegration Test

\begin{tabular}{lcccccccc}
\hline & \multicolumn{3}{c}{ Trace Test } & \multicolumn{5}{c}{ Eigenvalue Max Test } \\
\hline & $\mathrm{r} \leqslant 0$ & $\mathrm{r} \leqslant 1$ & $\mathrm{r} \leqslant 2$ & $\mathrm{r} \leqslant 3$ & $\mathrm{r} \leqslant 0$ & $\mathrm{r} \leqslant 1$ & $\mathrm{r} \leqslant 2$ & $\mathrm{r} \leqslant 3$ \\
\hline Australia & $49.70^{* * *}$ & 27.16 & 15.22 & 4.53 & $25.59 * * *$ & 11.94 & 10.70 & 4.53 \\
Canada & $51.19 * * *$ & 25.43 & 12.20 & 0.90 & $25.76 * * *$ & 13.23 & 11.30 & 0.90 \\
Chile & $85.98 * *$ & $43.28 * *$ & 7.12 & 3.32 & $42.70 * *$ & $36.16 * *$ & 3.80 & 3.32 \\
Denmark & $49.36 * *$ & 28.49 & 13.75 & 6.37 & 20.87 & 14.74 & 7.37 & 6.37 \\
Japan & $87.58 * *$ & $33.75 * * *$ & 15.78 & 4.95 & $53.83 * *$ & 17.97 & 10.83 & 4.95 \\
Mexico & $62.81 * *$ & 30.89 & 13.20 & 4.89 & $31.92 * *$ & 17.69 & 8.30 & 4.89 \\
New Zealand & $78.74 * *$ & 31.46 & 15.67 & 4.93 & $47.28 * *$ & 15.79 & 10.73 & 4.93 \\
Norway & $61.35 * *$ & 24.22 & 14.42 & 5.75 & $37.12 * *$ & 9.80 & 8.67 & 5.75 \\
South Africa & $87.34 * *$ & $36.61 * *$ & 10.83 & 2.77 & $50.74 * *$ & $25.77 * *$ & 8.06 & 2.77 \\
South Korea & $106.21 * *$ & $46.99 * *$ & 17.02 & 3.84 & $59.21 * *$ & $29.97 * *$ & 13.18 & 3.84 \\
Sweden & $61.61 * *$ & 21.09 & 8.65 & 2.01 & $40.52 * *$ & 12.44 & 6.64 & 2.01 \\
Switzerland & $90.97 * *$ & $41.97 * *$ & $21.47 * *$ & 7.36 & $49.00 * *$ & $20.49 * * *$ & $14.11 * * *$ & 7.36 \\
U.K. & $57.49 * *$ & 24.85 & 9.76 & 2.63 & $32.64 * *$ & 15.09 & 7.12 & 2.63 \\
$*$ ***) (***) indicate the rejection of the null at $1 \%, 5 \%$, and $10 \%$ level of significance respectively. & & & \\
\hline
\end{tabular}

The structural break tests of Andrews (1993) and Andrews and Ploberger (1994) are applied to assess the stability of the relationship between the US dollar, monetary fundamentals, and real oil prices. To obtain these test statistics, we estimate the following vector error correction model via OLS.

$$
e_{j, t}=\alpha+\sum_{i=1}^{k} \beta_{i} e_{j, t}+\gamma\left(m_{t}-m_{t}^{*}\right)+\delta\left(y_{t}-y_{t}^{*}\right)+\sum_{i=1}^{k} \theta_{i} \Delta O i l_{t-i}+\phi E C T_{t-1}+\varepsilon_{t}
$$

where $e_{j, t}$ is the USD exchange rate versus the foreign country $\mathrm{j}$ at time $\mathrm{t} ;\left(m_{\mathrm{t}}-m_{\mathrm{t}}^{*}\right)$ denotes the US money supply relative to the foreign money supply; $\left(y_{t}-y_{t}^{*}\right)$ denotes the US 
output relative to the foreign output; $\Delta O i l_{t}$ is the percentage change of oil price at time $t$, $E C T_{t-1}$ is the error correction terms at time period $t-1$, the lag length $\mathrm{k}$ is chosen based on the Akaike information criteria (AIC), and $\varepsilon_{t}$ is the error term. Note that the error correction term is given as follows:

$$
E C T_{t}=e_{j, t}-\alpha_{0}-\alpha_{1}\left(m_{t}-m_{t}^{*}\right)-\alpha_{2}\left(y_{t}-y_{t}^{*}\right)-\alpha_{3} O i l_{t}
$$

In Table 2, we present the estimated break date and the corresponding structural break tests with asymptotic p-values computed by Hansen's (1997) approximation. It is evident that we cannot reject the null hypothesis of no structural break, which confirms the stability of the parameter estimates of the exchange rate's vector error correction equation at the $1 \%, 5 \%$, or $10 \%$ significant levels variously.

Table 2. Structural Break Tests

\begin{tabular}{lccccccc}
\hline & Break Date & Ave F & P-value & Sup F & P-value & Exp F & P-value \\
\hline Australia & $2008: \mathrm{Q} 4$ & 5.14 & 0.59 & 14.3 & 0.29 & 3.68 & 0.47 \\
Canada & $2007: \mathrm{Q} 2$ & 6.51 & 0.35 & 10.56 & 0.65 & 3.66 & 0.48 \\
Chile & $2002: \mathrm{Q} 4$ & 8.29 & 0.15 & $21.12^{*}$ & 0.03 & $7.17^{*}$ & 0.04 \\
Denmark & $1990: \mathrm{Q} 1$ & 5.98 & 0.43 & 11.92 & 0.49 & 3.59 & 0.50 \\
Japan & $1994: \mathrm{Q} 3$ & 3.48 & 0.90 & 14.12 & 0.30 & 3.19 & 0.61 \\
Mexico & $1993: \mathrm{Q} 2$ & 3.92 & 0.83 & 14.09 & 0.30 & 3.74 & 0.46 \\
New Zealand & $2007: \mathrm{Q} 2$ & $12.31 *$ & 0.03 & 18.59 & 0.08 & $7.29 *$ & 0.04 \\
Norway & $1991: \mathrm{Q} 3$ & 7.28 & 0.24 & 14.88 & 0.24 & 5.16 & 0.19 \\
South Africa & $2001: \mathrm{Q} 2$ & 4.84 & 0.65 & 13.82 & 0.32 & 3.49 & 0.65 \\
South Korea & $1996: \mathrm{Q} 3$ & 2.72 & 0.98 & 20.09 & 0.06 & 5.72 & 0.13 \\
Sweden & 2007:Q4 & 9.39 & 0.08 & 17.45 & 0.12 & 5.80 & 0.12 \\
Switzerland & $1993: \mathrm{Q} 4$ & 6.24 & 0.38 & 14.51 & 0.27 & 5.05 & 0.20 \\
U.K. & 2008:Q4 & 9.42 & 0.08 & 14.96 & 0.34 & 5.53 & 0.14 \\
\hline * denotes the failure to reject the null hypothesis at 1\% significance level. & & & \\
\hline
\end{tabular}

\subsection{The Impulse Response Function Analysis}

Figures $1-4$ display the response of the USD exchange rate to the identified structural shocks with $95 \%$ confidence interval bands. The derived monetary model of exchange rates suggests a negative link between oil prices and the USD exchange rates. Figure 1 illustrates the response of the USD exchange rate to a real oil price shock and indicates that higher oil prices are associated with the depreciation of the USD exchange rate against all currencies except the Australian dollar. In other words, the plotted impulses indicate that a one-standard deviation shock to the real price of oil is followed by a depreciation of the USD exchange rate against 12 of the 13 currencies, with the depreciation rate ranging between 0.002 and 0.018 percent points. On the other hand, the USD against the Australian dollar experiences an 


\section{MlMacrothink}

Research in Applied Economics

ISSN 1948-5433

2018, Vol. 10, No. 4

appreciation rate of 0.016 percent point as a result of a one-standard deviation shock to the real price of oil. It is also worthy to note that the results indicating the negative relationship between oil prices and the USD exchange rates are consistent with the findings of previous studies, such as Chaudhuri and Daniel (1998), Sadorsky (2000), Chen and Chen (2007), and Uddin et al. (2014).

The monetary model of exchange rates posits a negative relationship between the nominal exchange rate and relative output. The plotted impulses, as shown in Figure 2, illustrate the response of the USD exchange rate to real output shocks, with mixed results. In particular, a positive shock to relative output causes the USD exchange rate to increase (depreciate) immediately against four currencies whereas it declines (appreciates) immediately against nine currencies. For example, we find the immediate response of a one-standard deviation shock to relative output causes the nominal exchange rate to appreciate by 0.002 and 0.008 percent points for Chile and Sweden respectively.

Furthermore, the derived monetary model of exchange rates suggests a positive relationship between relative money supply and nominal exchange rates. Figure 3 illustrates the responses of the USD exchange rate to a positive shock to the relative money supply. We find the responses of the USD to a positive shock to the nominal money supply indicate an appreciation against ten currencies and a depreciation against four. For instance, we find that the immediate response of a one-standard deviation shock to the relative money supply leads to the depreciation of the USD against the Mexican peso by 0.016 percent points. It is worthy to note that the reported findings regarding the impacts of monetary fundamentals on the movements of the USD exchange rate are consistent with the findings of Rapach and Wohar (2002) for Australia, Canada, Denmark, and Sweden, Lizardo and Mollick (2010) for Mexico and the UK, Hunter and Ali (2015) for Japan, and Bruyn et al. (2013) for South Africa.

Lastly, the impact of a positive shock to the exchange rate of the USD to itself is shown in Figures 4. The plotted impulses show that the USD rises (depreciates) during the first two quarters then starts declining (appreciating) in the remaining time period against most currencies. The plotted impulses indicate that the USD increases (depreciates) against the currencies of Canada, Mexico, Norway, and South Africa until the fourth or fifth quarter, and then it starts to decrease (appreciate) or stabilize until the end of the time period. We find the response of the USD against the New Zealand currency to be positive (depreciating) until the fifth quarter, and then it stabilizes over the remaining period. To summarize, we find that a one-standard deviation shock to the USD exchange rate leads to the depreciation of the USD exchange rate within a range of 0.020 and 0.041 percent points. 

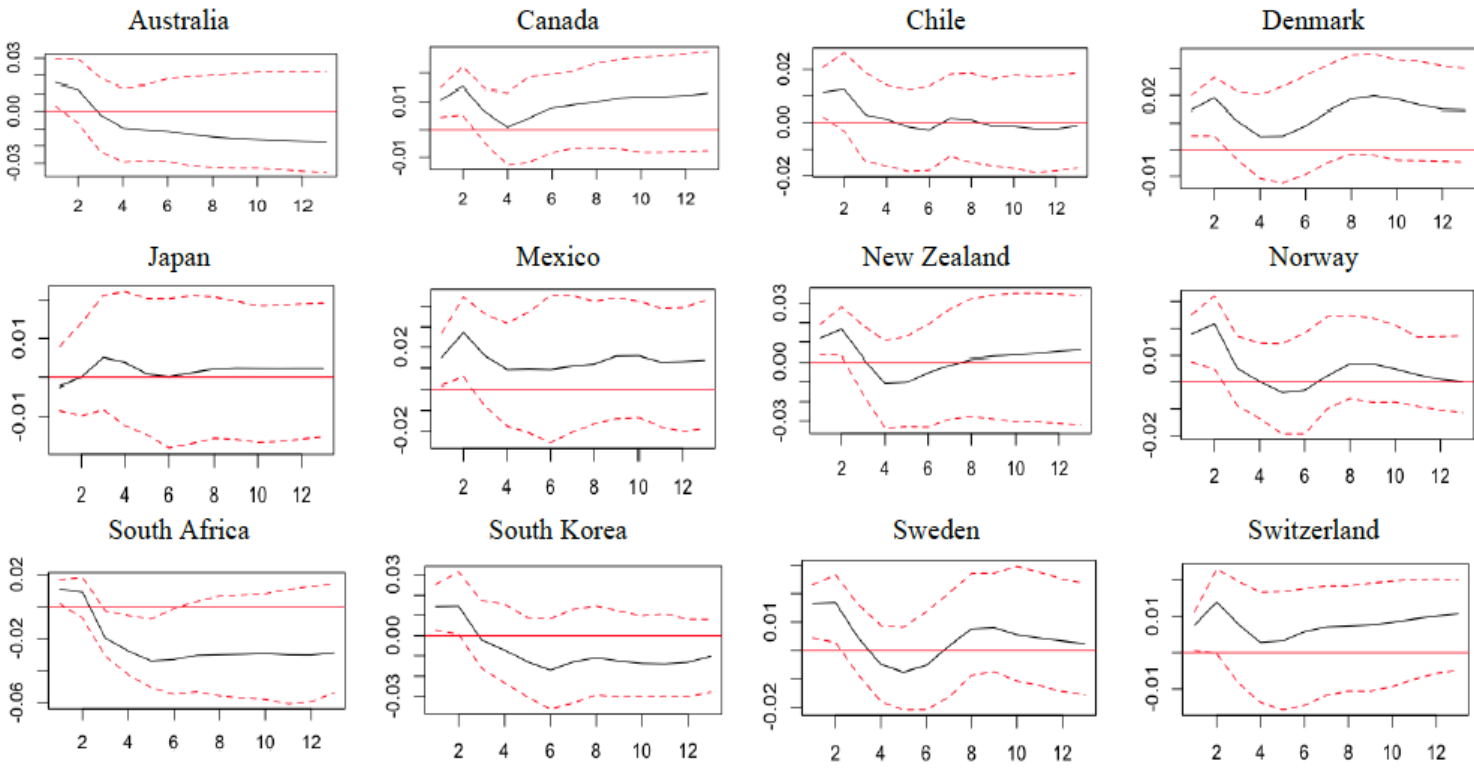

UK

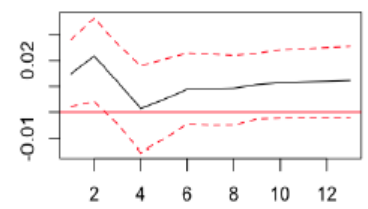

Figure 1. The Response of the USD Exchange Rate to Oil Price Shocks Note: The vertical axis represents the USD exchange rate whereas the horzintal axis represents time horizon "Quarters."
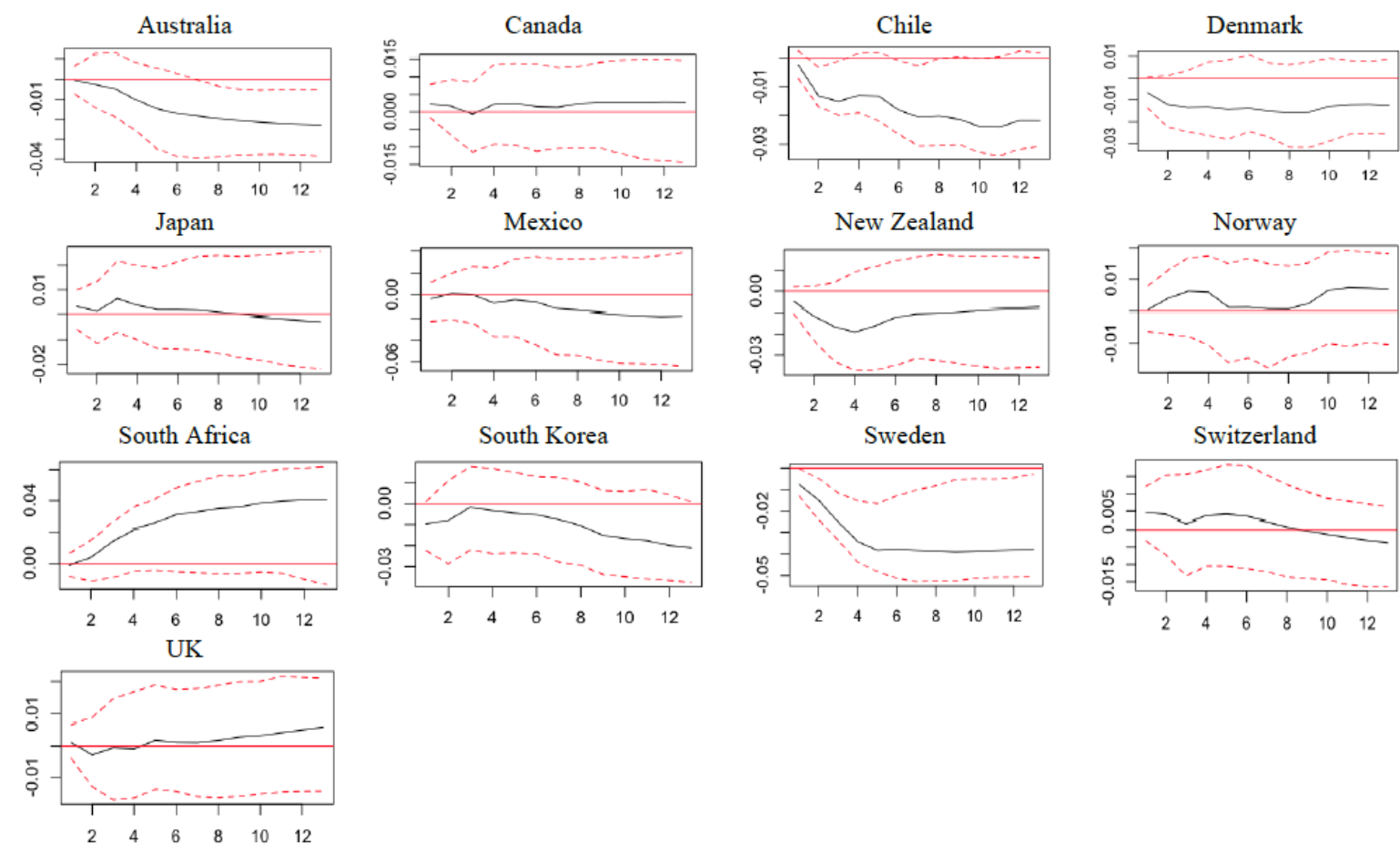

Figure 2. The Response of the USD Exchange Rate to Relative Output Shocks Note: The vertical axis represents the USD exchange rate whereas the horzintal axis represents time horizon "Quarters." 

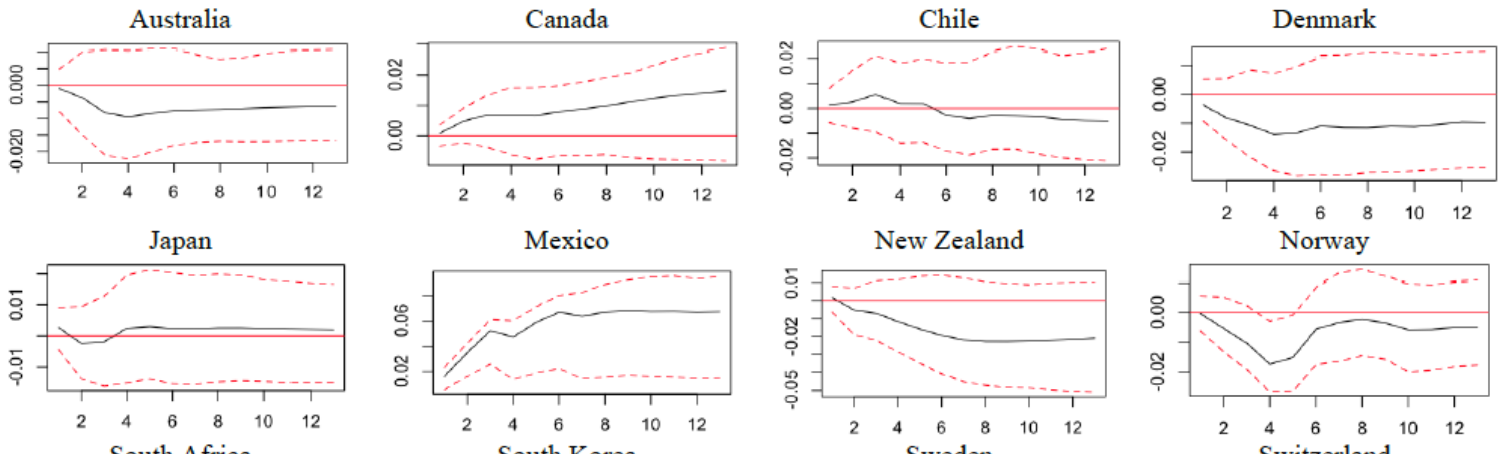

New Zealand
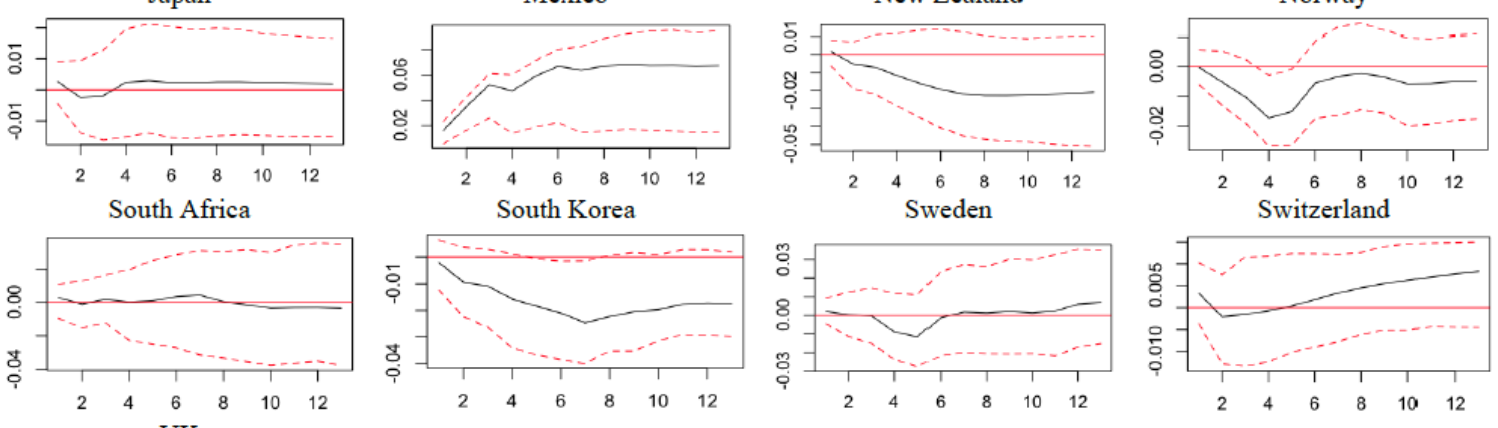

UK

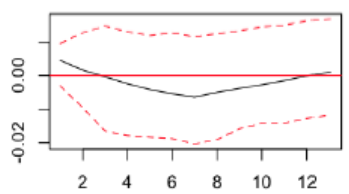

Figure 3. The Response of the USD Exchange Rate to Relative Money Supply Note: The vertical axis represents the USD exchange rate whereas the horzintal axis represents time horizon "Quarters."
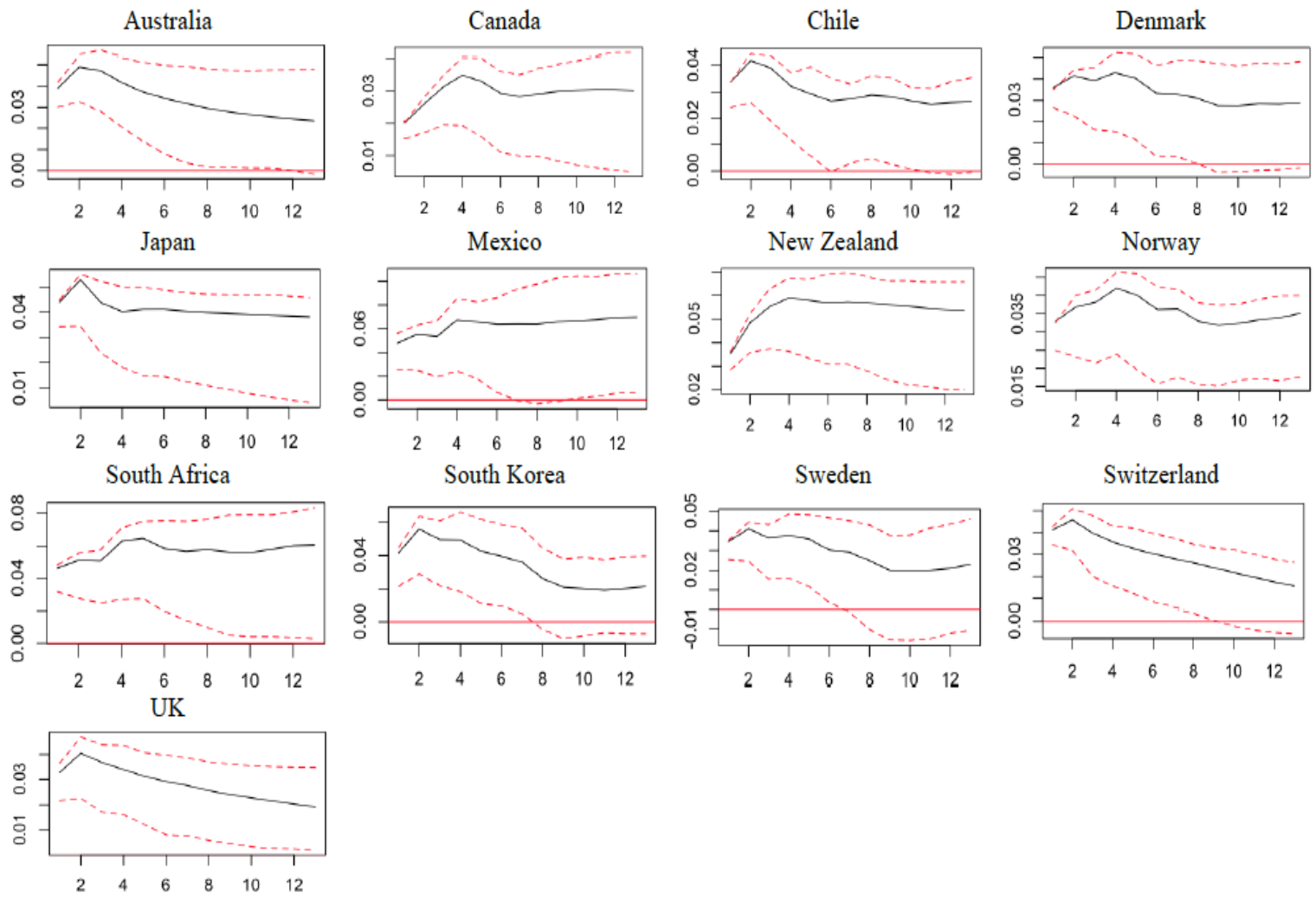

Figure 4. The Response of the USD Exchange Rate to Exchange Rate Shocks

Note: The vertical axis represents the USD exchange rate whereas the horzintal axis represents time horizon "Quarters 


\subsection{The Forecast Error Variance Decomposition}

While the impulse response function illustrates the qualitative response of the USD exchange rate to shocks in the price of oil and other structural shocks, the forecast error variance decomposition (FEVD) illustrates the relative importance of the structural shocks in explaining the variations of the USD exchange rate and the variations of other variables.

Table 3 presents the contribution of all structural shocks on the USD exchange rate based on the forecast error variance decomposition. Because the price of oil is ordered first in the VEC model, this decomposition assumes that the initial period has all variance in the forecasts attributed to the price of oil and none to the other variables. Therefore, we find that, as the forecast horizon increases, there is more variation attributed to the other changes based on the correlation of the changes and the dynamics of the system.

The forecast variation helps us to understand the important role of oil price shocks and other structural shocks in determining the movements of the USD exchange rate. It is evident from the results shown in Table 3 that the variation of the USD exchange rate is attributed largely to its own shocks, and as the forecast horizon increases, the contribution of the exchange rate shock on the movements of the USD declines.

Among the other structural shocks, we find the variation in the USD exchange rate is driven to some extent by oil price changes. In particular, we find that between $0.27 \%$ and $22.91 \%$ is attributed to the change in oil price during the first quarter. After eight quarters, or two years, the results indicate that the variation in the USD exchange rate attributed to the change in oil prices lies within a range of $0.34 \%$ and $15.02 \%$. This indicates a decline of the contribution of oil prices in explaining the movements of the USD exchange rates. However, we find that, as the forecast horizon increases, changes in oil prices yield more variation in the value of the USD against seven currencies. The USD variation lies approximately within a range of $6.01 \%$ and $15.12 \%$. Furthermore, the FEVD results indicate that the impact of monetary fundamentals on the USD variation tends to increase as the forecast horizon increases for most countries. However, the change attributable to monetary fundamentals is relatively small compared to the change attributable to the movement in oil prices. For example, the pattern of the forecast variation indicates that shocks to relative output (money supply) explain the USD fluctuations after twelve quarters or three years, within the range of $0.39 \%$ and $53.61 \%(0.24 \%$ and $16.79 \%)$.

In the case of the USD against the Japanese yen, changes in relative output play a larger role than changes in the relative money supply and oil prices. Strictly speaking, we find that changes in the value of the USD against the Japanese yen are attributed to changes in the relative output by approximately $0.78 \%$. However, about $0.54 \%$ of the USD variation is attributable to shocks to the price of oil after one year. As the forecast horizon increases, the contribution of the oil price and relative output shocks decreases; in other words, we find that oil and relative output shocks contribute to explaining roughly $0.34 \%$ and $0.39 \%$, respectively, of the movements of the USD exchange rate. 
Table 3. Forecast Error Variance Decomposition.

\begin{tabular}{|c|c|c|c|c|c|c|c|c|c|c|c|c|c|}
\hline \multirow[b]{2}{*}{ Variable } & \multirow{3}{*}{$\mathrm{H}$} & \multicolumn{4}{|c|}{ Australia } & \multicolumn{6}{|c|}{ Canada } & \multicolumn{2}{|l|}{ Chile } \\
\hline & & Oil & Y & EX & M & Oil & $\mathrm{Y}$ & EX & M & Oil & Y & EX & $\mathrm{M}$ \\
\hline & & Shock & Shock & Shock & Shock & Shock & Shock & Shock & Shock & Shock & Shock & Shock & Shock \\
\hline \multirow[t]{4}{*}{ USD } & 1 & 14.61 & 0.02 & 85.36 & 0.00 & 21.39 & 0.92 & 77.69 & 0.00 & 10.26 & 0.432 & 89.30 & 0.00 \\
\hline & 4 & 5.87 & 1.62 & 91.01 & 1.48 & 10.03 & 0.33 & 87.59 & 2.04 & 4.69 & 9.010 & 86.00 & 0.28 \\
\hline & 8 & 7.58 & 9.04 & 81.26 & 2.11 & 8.04 & 0.35 & 88.01 & 3.60 & 2.86 & 17.53 & 78.91 & 0.68 \\
\hline & 12 & 10.58 & 15.46 & 71.73 & 2.22 & 9.29 & 0.45 & 83.87 & 6.39 & 2.05 & 25.05 & 71.78 & 1.09 \\
\hline & & \multicolumn{4}{|c|}{ Denmark } & \multicolumn{4}{|c|}{ Japan } & \multicolumn{4}{|c|}{ Mexico } \\
\hline \multirow[t]{4}{*}{ USD } & 1 & 13.74 & 2.97 & 83.28 & 0.00 & 0.27 & 0.52 & 99.20 & 0.00 & 8.28 & 0.34 & 91.36 & 0.00 \\
\hline & 4 & 8.93 & 6.86 & 82.36 & 1.85 & 0.54 & 0.78 & 98.05 & 0.61 & 6.37 & 0.30 & 84.44 & 8.87 \\
\hline & 8 & 9.23 & 9.57 & 78.39 & 2.81 & 0.34 & 0.51 & 98.79 & 0.34 & 3.20 & 0.81 & 80.60 & 15.36 \\
\hline & 12 & 12.78 & 10.45 & 73.58 & 3.19 & 0.34 & 0.39 & 99.01 & 0.24 & 2.78 & 1.76 & 78.66 & 16.79 \\
\hline & & \multicolumn{3}{|c|}{ New Zealand } & & \multicolumn{4}{|c|}{ Norway } & \multicolumn{4}{|c|}{ South Africa } \\
\hline \multirow[t]{4}{*}{ USD } & 1 & 10.29 & 1.67 & 88.04 & 0.00 & 22.91 & 0.01 & 77.07 & 0.00 & 5.47 & 0.03 & 94.48 & 0.00 \\
\hline & 4 & 4.63 & 6.74 & 85.59 & 3.02 & 11.70 & 1.29 & 81.18 & 5.82 & 10.04 & 5.18 & 84.51 & 0.25 \\
\hline & 8 & 2.49 & 5.14 & 83.47 & 8.89 & 7.08 & 0.74 & 86.94 & 5.22 & 15.02 & 12.98 & 71.83 & 0.15 \\
\hline & 12 & 1.78 & 4.05 & 82.46 & 11.69 & 5.64 & 1.44 & 88.5 & 4.34 & 15.12 & 18.15 & 66.34 & 0.37 \\
\hline & & \multicolumn{3}{|c|}{ South Korea } & & \multicolumn{4}{|c|}{ Sweden } & \multicolumn{4}{|c|}{ Switzerland } \\
\hline \multirow[t]{5}{*}{ USD } & 1 & 10.00 & 4.68 & 85.31 & 0.00 & 18.09 & 3.82 & 78.08 & 0.00 & 3.20 & 1.20 & 95.58 & 0.00 \\
\hline & 4 & 4.29 & 1.58 & 91.43 & 2.69 & 7.23 & 24.87 & 66.27 & 1.61 & 4.51 & 0.78 & 93.75 & 0.95 \\
\hline & 8 & 6.36 & 2.03 & 81.69 & 9.91 & 4.13 & 43.70 & 50.32 & 1.83 & 4.34 & 0.85 & 94.06 & 0.74 \\
\hline & 12 & 8.03 & 6.67 & 72.14 & 13.15 & 3.39 & 53.61 & 41.61 & 1.37 & 6.01 & 0.83 & 91.75 & 1.40 \\
\hline & & \multicolumn{4}{|c|}{ United Kingdom } & & & & & & & & \\
\hline \multirow[t]{4}{*}{ USD } & 1 & 16.96 & 0.09 & 82.93 & 0.00 & & & & & & & & \\
\hline & 4 & 13.83 & 0.15 & 84.50 & 1.49 & & & & & & & & \\
\hline & 8 & 11.50 & 0.19 & 83.99 & 4.30 & & & & & & & & \\
\hline & 12 & 13.37 & 0.67 & 81.66 & 4.29 & & & & & & & & \\
\hline
\end{tabular}

Note: Y shock represent the relative output shock, EX shock represents the exchange rate shock, and M shock represents the relative money

supply shock.

\subsection{The Out-of-Sample Forecast}

Table 4 shows the resulting forecast accuracy measures. Based on the mean square error (MSE) ratio, we find evidence indicating that the composite model outperforms the benchmark model in predicting the movements of the US dollar for eight currencies. In addition, the MSE-T statistics are larger than the critical value in eight cases. Thus, we strongly reject the null of equal mean squared forecast errors, indicating that the one-step-ahead forecast errors from the benchmark model are significantly larger than those from the composite model.

Finally, the ENC-T statistics are larger than the critical value in eight cases. This in turn 
suggests that the composite model contains added information for the US dollar exchange rate for eight currencies. Thus, the composite model encompasses the benchmark model in eight of the cases. Overall, these forecasting accuracy measures indicate that the price of oil enhances the predictability power of the monetary model of exchange rate.

Table 4. Forecasting Accuracy Measures

\begin{tabular}{|c|c|c|c|c|c|}
\hline Test & 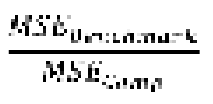 & WSE & $T$ & ENC & $T$ \\
\hline Australia & $1.42 *$ & $6.90^{*}$ & & $6.67 *$ & \\
\hline Canada & 0.59 & -2.44 & & -0.29 & \\
\hline Chile & $1.06^{*}$ & $1.60^{*}$ & & $1.75^{*}$ & \\
\hline Denmark & $2.89^{*}$ & $2.53^{*}$ & & $3.70^{*}$ & \\
\hline Japan & $1.12 *$ & $1.87^{*}$ & & $1.97 *$ & \\
\hline Mexico & 0.52 & -2.17 & & -0.12 & \\
\hline New Zealand & $3.99^{*}$ & $6.32 *$ & & $7.23 *$ & \\
\hline Norway & $2.92 *$ & $2.58^{*}$ & & $7.27 *$ & \\
\hline South Africa & 0.77 & -2.91 & & -2.21 & \\
\hline South Korea & 1.00 & 0.07 & & 0.22 & \\
\hline Sweden & $2.99^{*}$ & $4.21^{*}$ & & $5.47 *$ & \\
\hline Switzerland & $5.45^{*}$ & $10.31 *$ & & $9.72 *$ & \\
\hline U.K. & 0.63 & -2.92 & & -0.39 & \\
\hline
\end{tabular}

\section{Conclusion}

The main objective of this paper is to investigate the impact of higher oil prices on the value of the USD against 13 major currencies, using quarterly data over the period 1986:Q1 through 2014:Q3. To meet this objective, we derived a flexible monetary model of the exchange rate containing the real price of crude oil. Since our cointegration results indicate the existing of at least one cointegrating relationship between oil prices, monetary fundamentals, and the USD exchange rate, we estimated a vector error correction model and analyzed the effects of oil price movements on the USD exchange rate by computing impulse response functions. We find evidence of a negative relationship between oil prices and the USD exchange rate. Furthermore, the forecast error variance decomposition analysis suggests that shocks to the real price of oil play a larger role in the movements of the USD exchange rate than do monetary fundamentals. We also find evidence suggesting an essential role of oil price in enhancing the forecasting power of the flexible monetary model of the exchange rate based on three measures of forecasting accuracy.

These results of this study have implications for policy makers, economic researchers, and traders. The USD depreciation, as suggested by economic analysis, has positive and negative effects on the US economy. First, the depreciation of the USD helps in reducing the US trade 
deficit, since the fall of the USD increases the price competitiveness of US exports in foreign markets and decreases the price competitiveness of foreign goods in the US market. This, in turn, will increase employment since there will be less demand subtracted from the economy. In other words, higher US exports will improve domestic economic activity and improve employment, while lower imports of foreign goods means less domestic spending on foreign goods resulting in a boost to the domestic economy and employment.

Second, world commodity prices tend to increase as a result of the depreciation of the US dollar. For instance, when the USD experienced a sharp depreciation between 2002 and 2007, there was a sharp surge in gold prices from $\$ 300$ per ounce to more than $\$ 600$ per ounce, and crude oil price increased from $\$ 20$ per barrel to approximately $\$ 140$ per barrel. The index of non-fuel commodity prices also experienced an increase by $85 \%$. Third, the depreciation of the USD discourages foreign investors from holding dollar assets due to the low expected return. Finally, the depreciation of the USD reduces the US net foreign debt. This is possible because US foreign assets and US foreign liabilities are denominated in foreign currencies and USD, respectively. So, a real depreciation of the USD tends to raise the value of US external assets, while the value of US external liabilities does not rise. Consequently, this reduces the US external debt.

\section{References}

Akram, Q.F. (2004). Oil prices and exchange rates: Norwegian evidence. The Econometrics Journal, 7(2), 476-504. https://doi.org/10.1111/j.1368-423X.2004.00140.X

Al Rasasi, M. (2017). Oil prices and GCC exchange rates. Energy Sources, Part B: $\begin{array}{llll}\text { Economics, } \quad \text { Planning, } \quad \text { and } & \text { 344-350. }\end{array}$ https://doi.org/10.1080/15567249.2015.1132284

Al Rasasi, M. (2018). The response of G7 real exchange rates to oil price shocks. International Journal of Economics and Finance, 10(4), 191-205. https://doi.org/10.5539/ijef.v10n4p191

Al Rasasi, M., \& Banafea, W. (2015). The effects of oil shocks on Saudi Arabian economy. The Journal of Energy and Development, 41(1-2), 31-45.

Al Rasasi, M., \& Yilmaz, M. (2016). The effects of oil Shocks on Turkish macroeconomic aggregates. International Journal of Energy Economics and Policy, 6(3), 471-476.

Amano, R.A., \& van Norden, S. (1998). Exchange rates and oil prices. Review of International Economics, 6(4), 683-694. https://doi.org/10.1111/1467-9396.00136

Andrews, D. (1993). Tests for parameter instability and structural change with unknown change Point. Econometrica, 61(4), 825-66. https://doi.org/10.1111/1468-0262.00405

Andrews, D., \& Ploberger, W. (1994). Optimal tests when a nuisance parameter is present only under the Alternative. Econometrica, 62(6), 1383-414. https://doi.org/10.2307/2951753 


\section{$\triangle$ Macrothink}

Bahmani-Oskooee, M., \& Malixi, M. (1991). Exchange rate sensitivity of the demand for money in developing countries. Applied Economics, 23(8), 1377-1383. https://doi.org/10.1080/00036849100000060

Bruyn, R., Gupta, R., \& Stander, L. (2013). Testing the monetary model for exchange rate determination in South Africa: evidence from 101 years of data. Contemporary Economics, 7(1), 19-32. https://doi.org/10.5709/ce.1897-9254.71

Chaudhuri, K., \& Daniel, B.C. (1998). Long - run equilibrium real exchange rates and oil prices. Economics Letters, 231-238. https://doi.org/10.1016/S0165-1765(97)00282-6

Chen, SS., \& Chen, HC. (2007). Oil prices and real exchange rates. Energy Economics, 29(3), 390-404. https://doi.org/10.1016/j.eneco.2006.08.003

Chen, Y-C., \& Rogoff, K. (2003). Commodity currencies. Journal of International Economics, 60(1), 133-160. https://doi.org/10.1016/S0022-1996(02)00072-7

Chinn, M., \& Moore, M. (2011). Order flow and the monetary model of exchange rate: evidence from a novel data set. Journal of Money, Credit, and Banking, 43(8), 15991624. https://doi.org/10.1111/j.1538-4616.2011.00460.x

Chueng, Y-W., Chinn, M.D., \& Pascual, A. G. (2005). Empirical exchange rate models of the nineties: are any fit to survive? Journal of International Money and Finance, 24(7), 1150-1175. https://doi.org/10.1016/j.jimonfin.2005.08.002

Clarida, R., \& Gali, J. (1994). Sources of real exchange rate fluctuations: how important nominal shocks? Carnegie-Rochester Conference Series on Public Policy, 41(0), 1-56. https://doi.org/10.1016/0167-2231(94)00012-3

Clark, T.E., \& McCracken, M.W., 2001. Tests of equal forecast accuracy and encompassing for nested models. Journal of Econometrics, 105(1), 85-110. https://doi.org/10.1016/S0304-4076(01)00071-9

Dickey, D. A., \& Fuller, W. A. (1979). Distribution of the estimators of autoregressive time series with a unit root. Journal of the American Statistical Association, 74(366), 427-431. . https://doi.org/10.2307/2286348

Diebold, F.X., \& Mariano, R.S. (1995). Comparing predictive accuracy. Journal of Business and Economic Statistics, 13(3), 85-110.

Engle, R.F., \& Granger, C.W.J. (1987). Cointegration and error correction: representation, estimation, and testing. Econometrica, 55(2), 251-276. https://doi.org/10.2307/1913236

Evans, M.D.D., \& Lothian, J. R. (1993). The response of exchange rates to permanent and transitory shocks under floating exchange rates. Journal of International Money and Finance, 12(6), 563-586. https://doi.org/10.1016/0261-5606(93)90026-8

Frankel, J.A., \& Rose, A. K. (1995). Empirical research on nominal exchange rate. Handbook of International Economics. In: G. M. Grossman \& K. Rogoff (ed.), edition 1, volume 3, 
chapter 33, pages 1689-1729 Elsevier.

Groen, J.J. (2000). The monetary exchange rate model as a long-run phenomenon. Journal of $\begin{array}{lll}\text { International } & \text { Economics, } & \text { 200-319. }\end{array}$ https://doi.org/10.1016/S0022-1996(00)00061-1

Hall, S.G., Swamy, P.A.V.B., \& Tavlas, G.S. (2012). Milton Friedman, the demand for money, and the ECB's monetary policy strategy. Federal Reserve Bank of St. Louis Review, May/June, 153-186. https://doi.org/10.20955/r.94.153-186

Hansen, B. E. (1997). Approximate asymptotic p values for structural-change tests. Journal of Business and Economic Statistics, 15(1), 60-67. https://doi.org/10.1080/07350015.1997.10524687

Harvey, D.I., Leybourne, S.J., \& Newbold, P. (1998). Tests for forecast encompassing. Journal of Business and Economic Statistics, 16(2), 254-259.

Huang, Y., \& Guo, F. (2007). The role of oil price shocks on China' real exchange rate. China Economic Review, 18(4), 403-416. https://doi.org/10.1016/j.chieco.2006.02.003

Hunter, J., \& Ali, F. M. (2014). Money demand instability and real exchange rate persistence in the monetary model of USD-JPY exchange rate. Economic Modelling, 40(C), 42-51. https://doi.org/10.1016/j.econmod.2014.03.019

Jahan-Parvar, MR., \& Mohammadi., H. (2008). Oil Prices and Real Exchange Rates in Oil-Exporting Countries: A Bounds Testing Approach. MPRA Paper with number 13435, University Library of Munich, Germany, pp. 1-14.

Johansen, S., \& Juselius, K. (1990). Maximum Likelihood Estimated and Inference on Cointegration with Application to the Demand for Money. Oxford Bulletin of Economics and Statistics, 52(2) 169-210. https://doi.org/10.1111/j.1468-0084.1990.mp52002003.x

Kim, Y., \& Ying, H. (2007). An empirical assessment of currency devaluation in East Asian countries. Journal of International Money and Finance, 26(2), 265-283. https://doi.org/10.1016/j.jimonfin.2006.11.004

Kwiatkowski, D., Phillips, P. C. B., Schmidt, P., \& Shin, Y. (1992). Testing the Null Hypothesis of Stationarity against the Alternative of a Unit Root. How sure are we that Economic Time Series have a Unit Root? Journal of Econometrics, 54(1-3), 159-178. https://doi.org/10.1016/0304-4076(92)90104-Y

Lastrapes, W. D. (1992). Sources of Fluctuations in Real and Nominal Exchange Rates. Review of Economics and Statistics, 74(3), 530-539. https://doi.org/10.2307/2109498

Lizardo, R. A., \& Mollick, A.V. (2010). Oil price fluctuations and U.S. dollar exchange rates. Energy Economics, 32(2), 399-408. https://doi.org/10.1016/j.eneco.2009.10.005

MacDonald, R., \& Taylor, M. (1992). Exchange Rate Economics: A Survey. International Monetary Fund Staff Papers, 39(1), 1-57. https://doi.org/10.2307/3867200 
Mark, N., (2001). International Macroeconomics and Finance: Theory and Econometric Methods ( $1^{\text {st }}$ Ed.). Blackwell Publisher Inc.

Meese, R. A. (1990). Currency Fluctuations in the Post-Bretton Woods Era. Journal of Economic Perspectives, 4(1), 117-134. https://doi.org/10.1257/jep.4.1.117

Meese, R.A., \& Rogoff, K. (1983). Empirical exchange rate models of the Seventies: Do they fit out of sample? Journal of International Economics, 14(1-2), 843-883. https://doi.org/10.1016/0022-1996(83)90017-X

Meese, R.A., \& Rose, A.K., (1991). An Empirical Assessment of Non-linearities in Models of Exchange Rate Determination. Review of Economic Studies, 58(3), 603-619. https://doi.org/10.2307/2298014

Mohammadi. H., \& Jahan-Parvar, MR. (2012). Oil prices and exchange rates in oil-exporting countries: evidence from TAR and M-TAR models. Journal of Economics and Finance, 36(3), 766-779. https://doi.org/10.1007/s12197-010-9156-5

Narayan, P.K., Narayan, S., \& Prasad, A. (2008). Understanding the oil-exchange rate nexus for the Fiji islands. Energy Economics, 30(5), 2686-2696. https://doi.org/10.1016/j.eneco.2008.03.003

Neely, S.J., \& Sarno, L. (2002). How Well Do Monetary Fundamentals Forecast Exchange Rates? Federal Reserve Bank of St. Louis Review, 84(5), 51-74. https://doi.org/10.20955/wp.2002.007

Phillips, P. C.B., \& Perron, P. (1988). Testing for a Unit Root in Time Series Regression. Biometrica, 75(2), 335-346. https://doi.org/10.1093/biomet/75.2.335

Rapach, D. E., \& Wohar, M. E. (2002). Testing the monetary model of exchange rate determination: new evidence from a century of data. Journal of International Economics, 58(2), 359-385. https://doi.org/10.1016/S0022-1996(01)00170-2

Sadorsky, P. (2000). The empirical relationship between energy future prices and exchange rates. Energy Economics, 2253-266. https://doi.org/10.1016/S0140-9883(99)00027-4

Thalassinos, E.J., \& Politis, E.D. (2012). The evaluation of the USD currency and the oil prices: A VAR Analysis. European Research Studies, XIV(2), 137-146.

Throop, A. W. (1993). A Generalized Uncovered Interest Rate Parity Model of Exchange Rates. Federal Reserve Bank of San Francisco Economic Review, 2, 3-16.

Uddin, G. S., Tiwari, A. K., Arouri, M., \& Teulon, F. (2014). On the relationship between oil price and exchange rates: A wavelet analysis. IPAG Business School Working paper series 2014-456.

Valadkhani, A. (2008). Long and Short-Run Determinants of the Demand for Money in the Asian-Pacific Countries: An Empirical Panel Investigation. Annals of Economics and Finance, 9(1), 77-90. 
Zhou, S. (1995). The Response of Real Exchange Rates to Various Economic Shocks. Southern Economic Journal, 61(4), 936-954. https://doi.org/10.2307/1060733

Note

Note 1. See Mark 2001 for further discussion.

\section{Copyright Disclaimer}

Copyright for this article is retained by the author(s), with first publication rights granted to the journal.

This is an open-access article distributed under the terms and conditions of the Creative Commons Attribution license (http://creativecommons.org/licenses/by/3.0/). 